\title{
Regional Inequality of Economic and Social Developments in Albania
}

\author{
Bukuri Dumani \\ University of Tirana, \\ Faculty of Economics, \\ Tirana, Albania \\ Ines Nurja \\ University of New York Tirana, \\ Tirana, Albania \\ Blerina Subashi \\ Institute of Statistics, \\ Tirana, Albania \\ Nexhmedin Dumani \\ Mediterranean University of Albania, \\ Tirana, Albania
}

DOI: https://doi.org/10.36941/ajis-2020-0o78

\begin{abstract}
The economic and social developments in Albania, apart from being the lowest in the region, also differ significantly among prefectures. This article aims to analyze the economic and social developments with the focus to inequality, especially in education. Improving the economic and social situation in the country and expecially in prefectures requires policies that mobilize economic and financial resources as well as human capital for the country. Also especially in the prefectures where economic and social developments are low and very low; whereas the growth of education can be supported on a territorial approach, with concrete local and national policies to stimulate the demand for secondary school entry and to provide contemporary education services, especially policies in favor of children in economic disadvantage, in rural and peri-urban areas. In this study different data sources are combined such as Labor Force Survey (LFS 2018), Demographic and Health Survey, (ADHS 2017-2018), Family Budget Survey (HBS 2018), Living Standards Survey (LSMS 2012) the Human Development Report (HDR) 2018 and Census 2011. The collection, integration and analysis of new data are necessary to have a general and concrete view to inform development policies, to advance reflection on development and to design the best solutions. The results obtained show that many of the economic and social developments in some prefectures are about twice as low as those in the bestperforming prefectures in the country. Focusing on education, its level goes hand in hand with other developments in prefectures; prefectures with lower economic indicators also have lower participation in education and educational attainment.
\end{abstract}

Keywords: economic and social development, inequality, educational participation, risk factors 


\section{Introduction}

People expect to see progress in different aspects of their life including the economic situation; otherwise the figures would only be a statistical construct. They are more indifferent to the growth of the gross domestic production (GDP) than to the high noisy music of clubs. Differences, poverties and inequalities often are not visible even though living indicators grow on average. These growths do not affect everyone in the same way. Different analysis should be done in order to get a better understanding of their life beyond that what "average growth" can show. Why would families or individuals care about how much the income per inhabitant has increased, when there are families/individuals in lack of basic human needs? Why would landless farmers care how much the agricultural production has changed?

Despite of the growth of Human Development Index (HDI) since decades, poverty and inequality are visible and tangible. Albania in 2018 had a better HDI ranking in relation to the Gross National Income, GNI, (hdr.undp.org, 2018). According to HDI, Albania ranks 23th places before its rank according to GNI. Social developments, especially education of the population have affected most significantly the HDI value for the country.

The Gross Domestic Production per capita in Albania is about 30\% ${ }^{1}$ of its value in the EU countries (data.worldbank.org). One adult in Albania has on average 10 years of schooling compared to 11-14 years in countries of the region and Europe (data.uis.unesco.org).

Despite of the limited economic and financial resources due to the low productivity of economy, the families and the government have considered education as an individual and social emancipation means, a privileged means for development (Dumani, Bici, Dumani 2017). Even though the educational developments in Albania compared to those economic are important, the registration of students in high schools remains low; $79 \%$ of students $15-17$ years old which have completed the obligatory nine-year education are registered in high schools (Demographic and Health Survey, 20172018), compared to over $85 \%$ for countries of the region and Europe (Bici, Dumani 2016). This figure it is just the same as it was 30 years ago. In 1990, $73 \%$ of pupils completing the eighth grade (en.wikipedia.org-education) has been registered in high school.

Albania's population, although is shifting of population age structures towards older populations over time is still one of the youngest in Europe; median age is 32.8 years, compared to 42.2 in 2018 in EU28 countries (en.wikipedia.org_median age).

One echo of economists where "demographic vitality is a condition for technical progress and economic growth" (Mazerolle 2005) requires engagement and force of action to fill the environment with more schooling and more qualitative education, innovation and technology.

What is the distribution of social and economic development according to prefectures? This article focuses on the economic and social performance of the prefectures with focus on inequalities, especially in education.

\section{Literature Review}

This article to examine the status of regional inequality in the economic and social development in Albania and to broaden the publications over the regional inequality.

Regional inequality is the uneven distribution of income and other variables among regions, representing changes in the living standards and in the job opportunities among regions (oecd.org/regional). Despite the growing economic and social developments in Albania in the last decades, the country situation is far away from the other European countries in many indicators such as very low GDP per capita, insufficient access quality and quantity wise to services and

\footnotetext{
${ }^{1}$ In 2018, GDP per capita according to PPP in Albania was 13,325.3\$ from 43,715.3\$ for EU countries.
} 
infrastructure, higher portion of employment in agriculture, lower urbanization, high unemployment, considerable migration, low participation in middle education, etc. Within the country, there is clear regional differentiation and extreme differentiation in local level according to municipalities and comunes (Boeckhout, McClements, Girejko, Karaev, Kuqi, Lekaj, Mançellari, Marinov, Murthi, Shutina, Toto 2010).

Is it possible that the economic growth in a low development country distributes a more balanced development among regions, or the economic growth enhances the inequality in these countries? Several statistical indicators that measure inequality, such as Gini coefficient, variation coefficient, or explanatory coefficients of the relationship between variables, may indicate the same thing for different regions in different countries, while these countries differ considerably in their living standards. A considerable part of the population in some regions do not meet the minimum, basic standards of living, such as the case is for Albania.

The interaction of inequality and growth and the direction of causality in this relationship have been an extensively discussed topic with several questions but without clear answers both in the theoretical and empirical literature (Tafenau, Paas 2011).

Regional policy has been one of the most dynamic policies in the transition countries of Central and Eastern Europe (CEE) during the last two decades (Miljanović, Miletić, Đorđević, 2010).

In the empirical analysis it is found that economic growth and regional disparities are related negatively to each other in the Western European countries. In the Eastern European countries regional inequality increases in the periods of fast economic growth. (Tafenau, Paas 2011).The upward 'tide' of economic activity generates benefits for the national economy that are spread geographically in a fairly unbalanced way (Psycharis, Rovolis, Tselios, Pantazis 2014).

Many empirical studies have analysed the convergence of the Italian regions, but no evidence is provided on the causes of differences in productivity levels. Neo-classical theory suggests that the income of poorer regions will converge, in the long run, to that of the richer regions and that, as a consequence, the growth rate of a region is inversely correlated to its initial level of per capita income (Solow, as cited Aiello, Scoppa 200o)

This process of absolute convergence takes place when the regions share the same steady state level, in other words, when exogenous variables preferences, technology, demographic growth are equal for poor and rich regions. The endogenous growth theories (Romer, as cited Aiello, Scoppa 200o) predict that higher growth rates can be achieved by accumulating production factors in one region and, thus, regional disparities might rise during the growth process (Aiello, Scoppa, 20oo). Growth supporting policies in poor countries should first of all concentrate on achieving sustainable national growth, not on reducing regional disparities (Tafenau, Paas 2011).

When societies or populations dwell in low and very low living standards, would only a sustainable national growth be sufficient? Or, for the situation to change, it is necessary not only a growing development of the country, but also that such progress is distributed among regions and areas, especially in those regions, municipalities and communes that are extremely differentiated. People, families do not choose to live in misery (Pair 200o) but should be part of the policies to change the miserable statues where they find themselves.

Regional inequalities are a development problem and finding ways to overcome such inequalities is of great importance to the designing of regional policies (Iliev 2018).

Economic growth is affected by the human capital accumulation (education, skills, experience) as a result of its effects over the work productivity (Henaff, Lange, Martin 2009).

In neoclassical models, it is the initial stock of education that determines the long-term growth scale. A more educated, qualified labor force, all other things remaining the same, is more able to absorb and support modern technologies and innovation productivity (Henaff, Lange, Martin 2009).

Studies and analysis in Albania (Demographic and Health Survey, 2017-2018), (Bici, Dumani 2016), (Betti, Bici, Neri, Sohnesen, Thomo 2018) demonstrate the role of education in the development and lowering poverty.

If everyone agrees that education can play a role in the war against poverty, the nature and 
importance of this role remain debatable (Henaff, Lange, Martin 2009). Is it poverty that affects the education level or the low education or lack thereof affects the poverty? In the war against poverty, education should be developed independently of poverty, in order to enable a way out of poverty (Henaff, Lange, Martin 2009).

In the poor families, often parents who do not hold a diploma, cannot offer their children the necessary support, cannot offer material conditions (shelter, free time, etc) which promote educational development and success (Fougère 2007).

Poverty is not sufficient to explain non-participation (non-enrollment) of students in middle school education (Dumani, Bici, Dumani 2017). In order to stimulate and expand the high school education attendance, along with the education institutions, also the parents, families and society should be involved more in the ideology of children education. "Change society in order change school, change school in order to change society" is quoted in the header of the French magazine "Cahiers pedagogique" every month for about 40 years (Fougère 2007).

\section{Methodology and Data}

Descriptive and analytical methods are used in this article. Descriptive methods, such as average indicators, maps and figures apart from providing a quick and simple information on the level of development and its distribution among regions, also allows us to make a deeper research, more informative and analytical. Descriptive statistics are used in this study to represent the sectorial level of developments in economy, social and demography. These methods, although simple for information, are limited because they express in an unrelated way the developments according to sector. In order to better explain and argue relations and interdependencies between variables and factors in a summarized context of developments, different multivariate methods are applied, such as the Logistic Regression, Principal Component Analysis and Factor Analysis.

In this article we explain the importance of the participation in education of students that complete the obligatory nine-year level and that enroll in middle schools. There is a generally accepted consensus that education is a privileged instrument for development and that "education is an investment which returns can be calculated' (Henaff, Lange, Martin 2009). Actually, in Albania, the enrollment in middle school is low, and even lower in some prefectures in the country.

The logistic regression method it is used to analyze the influence and importance of various economic social and geographic explanatory variables in the (non)enrollment of students in the middle school. The best model estimated includes the variables: poverty, parents' education, home to school distance, number of children outside the labor age, lack of parent in the family. The data source used in the regression is LSMS2012. There were surveyed 6,671 households and the survey is representative in regions and prefectures ${ }^{2}$.

In order to analyze the developments and the regional inequalities in Albania, Principal Component Analyses and Factor Analysis are applied for the economic and sociodemographic variables. The data source are: LFS2018, HBS2018, ADHS 2017-2018; Census 2011. Based on the results obtained by the Factor Analysis, different graphs for regional inequalities and the distance of this inequality were created. These graphical output has to be considered as a important tool in the hands of policy makers for the country reforms.

The analyses are carried out using SPSS23, MATLAB R 2019b packages.

\footnotetext{
${ }^{2}$ INSTAT., In the DHS, LSMS 2012, LFS and HBS surveys, 15,823 families, 6,671 families, 7,932 families and 9,384 families were surveyed, respectively.
} 


\section{Results and Discussion}

\subsection{Demographic Profile}

In Census 2011, the total population of Albania enumerated is about 2.900 thousand. The administrative and territory division in Albania resulted in 12 prefectures (Figure 1). Population according to prefectures varies from 72 thousand inhabitants in Gjirokastër to 750 thousand inhabitants in Tirana prefecture (INSTAT, 2011). After Tirana, the prefectures of Fier, Elbasan, Durrës, Korça and Shkodra are among the biggest.

The population density varies from 25 inhabitants per $\mathrm{km}^{2}$ in Gjirokastër, to 450 inhabitants per $\mathrm{km}^{2}$ in Tirana; after Tirana, prefectures of Durrësi and Fieri are ranked with highest density.

Even though Albania is ageing, its population is still one of the youngest in Europe (Figure 1), after Kosova ${ }^{3}$. The median age of the population in 2018 is 32.9 compared to 42.2 in countries of EU28 (en.wikipedia.org_median age).

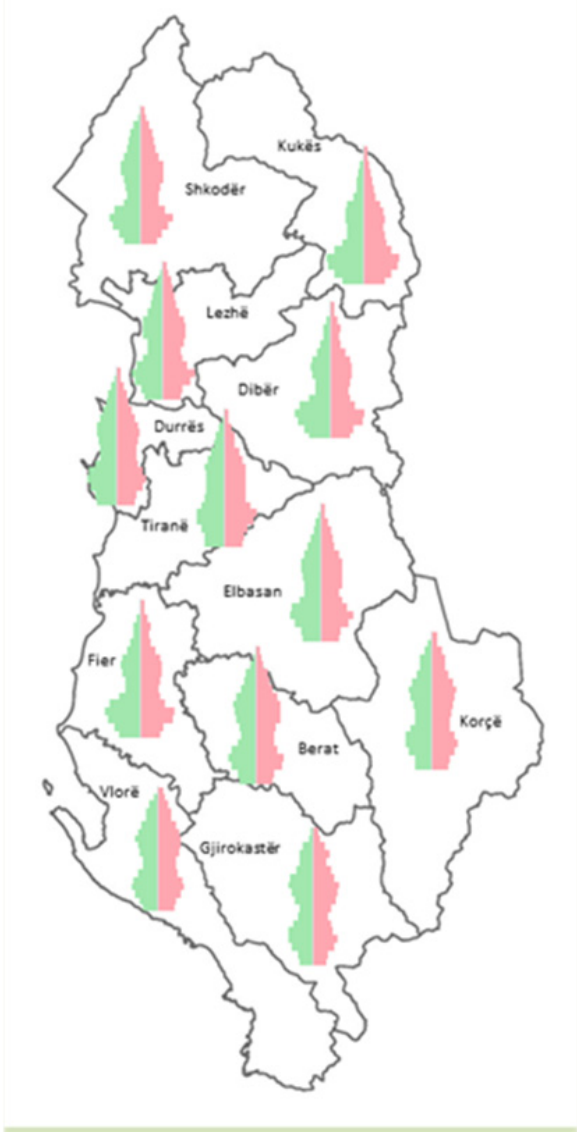

Figure 1. Age structure of Albania's population, Census 2011

\footnotetext{
${ }^{3}$ Kosova has the youngest population with a median age of 29 years old.
} 
As the number of births progressively declined, the base of the pyramid narrowed. The proportion of younger than 20 years old is higher in Kukës, Dibër, Lezhë and Shkodër; also these prefectures have higher young age dependency ratio. Kukës and Dibër have the lowest average age and Gjirokastër, Korçë and Vlorë have the highest (INSTAT, Census 2011).

\subsection{Economic and Social inequality}

The data analyses by prefectures show a characteristic association of economic and sociodemographic indicators between prefectures. In regions with high education rate, the GDP per capita is higher; the consumption per household is higher, the percentage of population in the higher quintile of wealth (assets) is higher and young age dependency ratio is lower.

Gross Domestic Production and the consumption per capita: in prefectures of Tirana, Durrës, Fier, Gjirokastër and Vlorë, the GDP per capita is higher (Figure 2). In prefectures of Kukës, Elbasan, Shkoder, Lezhë, Korçë, Dibër, the GDP per capita is about two times lower than in Tirana. Also, the average consumption per capita in FEE (Family Economic Entity) is lower in Kukës and Elbasan (Figure 3).

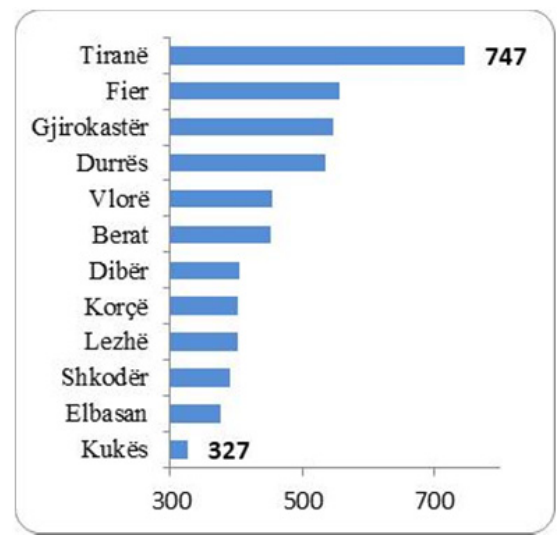

Figure 2. GDP per capita in prefectures (ooo/ ALL in 2017)

Source: INSTAT 2018, Household Budget Survey

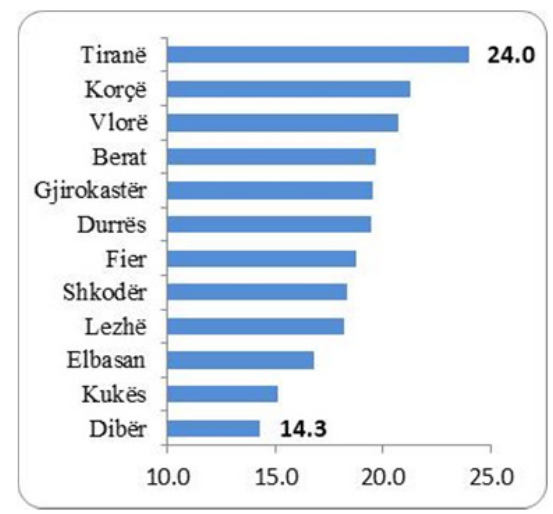

Figure 3. Consumption per capita in prefectures (ooo/ ALL in 2018)

Source: INSTAT 2018, Household Budget Survey 
The proportion of population in the lowest quintile of wealth belongs to prefectures of Diber, Kukes, Elbasan, respectively $58 \%, 47 \%$ and $41 \%$ of population (Demographic and Health Survey 2017-2018), whereas in the highest quintile of wealth there are about $2 \%$ of the population in Kukës and Dibër compare to $44 \%$ in Tiranë and $19 \%$ in Vlorë. The Gini Coefficient shows an unequal distribution of wealth, which differs clearly according to prefectures, from 0.06 in Durrës and o.11 in Vlorë to o.19 in Elbasan and 0.26 in Dibër (Demographic and Health Survey 2017-2018); more unequal in the rural areas (0.15) than in urban areas (0.05).

Employment and unemployment: unemployment rate is increased in all age groups, but it is higher amongst the young population (Figure 4$)^{4}$. The highest rate of unemployment both for male and female are found in age groups of 20-29, especially in $20-24$ years old. The proportion of population in the lowest quintiles of welfare (wealth) is higher when the unemployment is higher, and vice versa, when the unemployment is higher also the proportion of population in the lowest quintiles of welfare is higher (Demographic and Health Survey 2017-2018). Coefficients of activity are much lower for females in 2018 (INSTAT 2018).

The highest level of activity coefficients for males are reached in group age of 30 - 49 years old and for females in group age 25 - 49 years old. The higher employment is accompanied by a higher level of education, and on the other hand, employment is higher in the highest quintiles of wealth and vice versa. The highest rate of unemployed is registered in Dibër, Kukës, Lezhë, Shkodër, Elbasan (Demographic and Health Survey 2017-2018) both for females and males 5 .

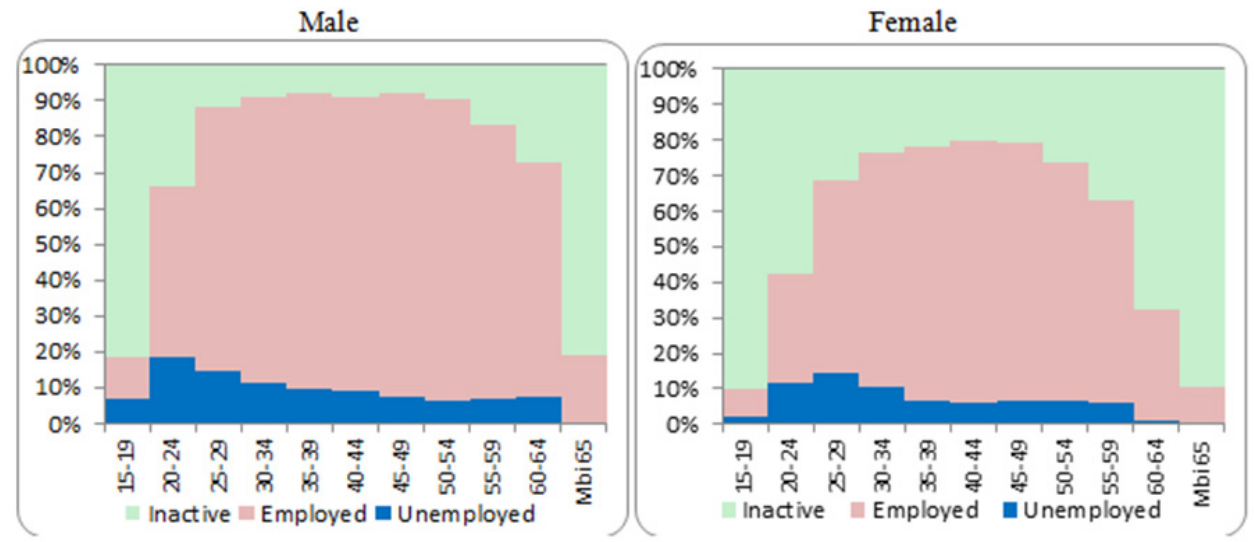

Figure 4. Employment and Unemployment in Albania, 2018

Source: Instat, LFS 2018 (own calculations)

Educational attainment and school attendance: Educational attainment in Albania compared to the EU countries for the population 25-64 years old ${ }^{6}$ differ considerably. In Albania almost half of the adults 25-64 years old have only one diploma at most a nine-years cycle, being about three times more than the EU countries and OECD. The population's percentage with high school education is also much lower. Whereas, the percentage of adults with high education is more than two times lower in Albania (Table 1) then in the EU countries.

\footnotetext{
${ }^{4}$ It is reported that unemployment in 2017 reached $12.8 \%$ (Instat, LFS 2018)

${ }^{5}$ Different definitions have been employed in ADHS and LFS

${ }^{6}$ The group age of $25-64$ has been considered for comparison to the EU countries.
} 
Table 1. Educational achievement for population 25-64 years old according to diploma level, 2014

\begin{tabular}{c|c|c|c|c|c}
\hline & \multicolumn{4}{|c|}{ Educational Achievement in \% } & \multirow{2}{*}{ Total } \\
\cline { 2 - 5 } & Up to elementary & $8 / 9$ years & High school & University & \\
\hline Albania & 8 & 42 & 35 & 15 & 100 \\
EU21 & 7 & 14 & 47 & 32 & 100 \\
OECD & 8 & 15 & 44 & 33 & 100 \\
\hline
\end{tabular}

Source: OECD. Stat Database (online education); For Albania: LSMS 2012

The average number of years of schooling (LSMS 2012) for 25 years old and above reaches 10.1 years ${ }^{7}$, which although raising is still far away from the levels of this indicator in some of the countries in the region such as Croatia, Montenegro, Serbia, Slovenia which average years of schooling 11-12 years and other developed countries in Europe where the average schooling years vary from 11 to 14 years (Dumani, Bici, Dumani 2018). The highest number of years of schooling for adults 25 years old and above belonged to UK with 13.8 years, Switzerland with 13.8 and Germany with 13.3 years (Bici, Dumani 2016).

The median number of years of schooling for the population of 6 years old and above both for female and male is higher in Tirana, Fier, Durrës and Vlorë. In other prefectures the median number of years of schooling for males is about two times lower than in the above-mentioned prefectures and for females about two times lower than in Tirana. The lowest median number of years of schooling is found in Dibër, Elbasan and Lezhë (Demographic and Health Survey 2017-2018).

The access to the education is strongly linked to the economic dimension. The median number of years completed in education is smaller in the lower quintiles and bigger in the higher quintiles of wealth (Figure 5). In the first and second quintiles the median number of completed years for population of 6 years old and above is about 7.5 years whereas in the fourth and fifth quintiles the median number of completed years of school is respectively 15 years and 15.6 years of schooling (Demographic and Health Survey 2017-2018).

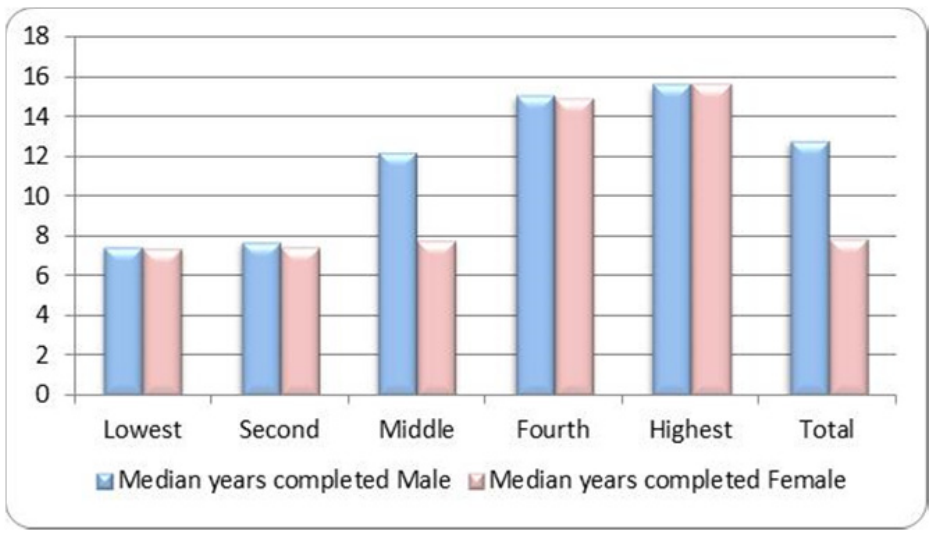

Figure 5. Percent distribution of the de facto female and male household population age 6 and over by highest level of schooling attended or completed and median years completed, Albania 2017-18 Source: ADHS 2018-2019 (own calculations)

\footnotetext{
${ }^{7}$ The median number of completed years of schooling for persons 6 years old and above reaches 10.3 years, ADHS 2017-18.
} 
In rural area, half of female of age 15-49 years old have over 8 years completed, whereas in the urban area half of females have completed over 15 years of schooling. The difference is smaller for male (Demographic and Health Survey 2017-2018). Prefectures of Tiranë, Vlorë, Gjirokastër and Durrës have the highest percentage of persons $15-49$ years old with university education and above, whereas in the other prefectures the portion of persons with university education is around twice as low, the lowest part of this category is in prefectures Dibër, Berat, Elbasan, Fier and Kukës. In Tiranë prefecture around one in three persons has a university education or above, being almost the same as EU and OECD countries (Dumani, Bici, Dumani, Subashi 2018).

The proportion of surveyed with higher education than secondary school in the 15-49 group age increases considerably with the welfare status, from $6 \%$ in the lowest quintile to $55 \%$ in the highest quintile for female and from $6 \%$ in the lowest quintile to $43 \%$ in the highest quintile for male (Demographic and Health Survey 2017-2018).

Despite of the population which is among youngest in Europe in 2018, only 66\% of the population uses internet (hdr.undp.org 2018) compared to over 90\% in the EU.

The government expenditures for education are still low, only 3.5\% of GDP (Demographic and Health Survey 2017-2018) from over $5 \%$ in the majority of European countries. Families in Albania, in 2018 , spend $3 \%$ of their budget for education and this indicator has decreased in recent years. The percentage of expenses for education in the family budget is lower in Dibër 1.2\%, in Elbasan 1.3\% and in Lezhë and Shkodër 1.5\% (INSTAT, HBS, 2018).

Based on the education indicators, in order to promote the debate of education quality and appropriate knowledge versus the obtained diploma, with the purpose of not reducing a diploma to just an instrument, but to have diplomas that are valid in the labor market (Bici, Dumani 2016).

\subsection{Enrollment of students in high school}

In Albania, school frequentation in the nine-year cycle is high $95 \%$ and does not vary from region or wealth. The net attendance ratio in high school (NAR) is $79 \%$, much lower than in the elementary school (Figure 6). Even though NAR has increased considerably compared to 2008-o9 from 56\% to $79 \%$ (Demographic and Health Survey 2017-2018), it still remains similar to 30 years ago. Around $73 \%$ of students completing 8-year cycle enrolled in high schools in 1990 (en. wikipedia.org_education).

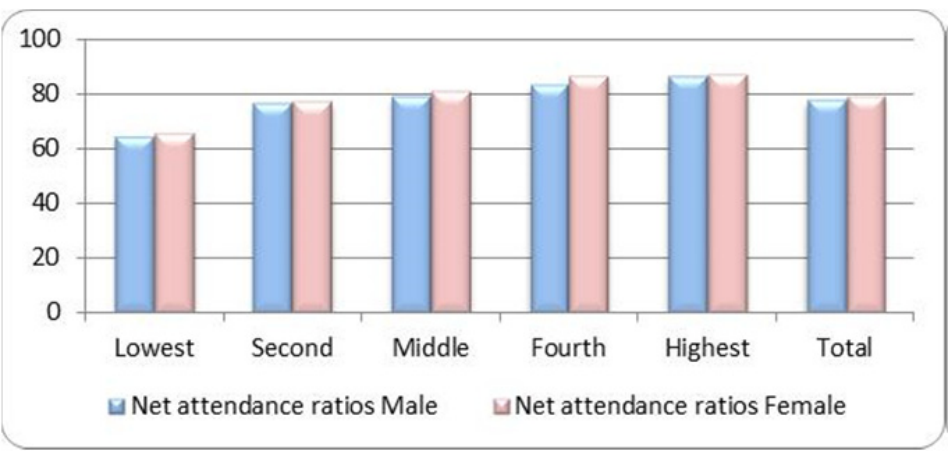

Figure 6. Net attendance ratios (NAR) for the de facto household population by sex and level of schooling, Albania 2017-18

Source: ADHS (own calculations)

The net attendance ratio in high school varies significantly by prefectures, from $64 \%$ in Dibër and $66 \%$ in Kukës, to $85 \%$ in Tiranë and $86 \%$ in Korçë. This indicator is lower in the lowest quintile of wealth and higher in the highest quintile respectively 66\% and 88\% (Demographic and Health Survey 
2017-2018). The low attendance in high school is faced with offer and demand issues.

Why then a part of students does not attend high school? Authors in (Bici, Dumani 2016) concluded that the three main reasons for not attending high schools, which account for about $80 \%$ of the cases are as follows:

a. Almost half of students consider their education completed by the nine-year basic cycle; $\mathbf{b}$. They are not interested to continue with further studies; c. Education is expensive.

Education expenditure is sensitive in family's economic problems. But, is poverty affecting the level of education, or vice versa?

The empirical analyses show that a complex relations between poverty and education, as well as their evolving character; it is not concluded from research any systematic correspondence between the poverty level and expenditure that families allocate to their children's education (D. Fougère, 2007).

Either in a difficult or even worse economic situation, families will spend for education only if their survival is guaranteed (Henaff, Lange, Martin 2009).

Even though poverty may become an obstacle not easy to surpass, the families' poverty is not sufficient to explain non-attendance of students; other factors may impact it, such as stronger involvement of the parents in the education ideology. Education also has an important compensatory role towards poverty and should convey the message that education must be pursued despite of poverty, succeeding in escaping from it (Fougère 2007). The enrollment rate remains low and is correlated with the poverty level or household structure (Bici, Dumani 2016). Education among the poor also plays an important role in remaining poor (Betti, Bici, Neri, Sohnesen, Thomo 2018).

When the majority of unenrolled students consider their education completed by nine years, do not have interest to pursue further, or feel insecure in the labor market, etc., then the efforts of the government, education institutions and their coordination with the families' efforts remain a possibility to incentivize the increase of demand for schooling.

Access to school is widely determined by the educational offer (Fougère 2007).

The educational offer should be able to make the high school diploma interesting and evaluated in the labor market, not an instrument diploma. Having a diploma does not always mean success, if their holders do not own the knowledge and do not respond to the market needs. Education is a powerful mechanism for development, if the policies for human capital utilization are effective.

When parents are more educated, poverty is in lower levels, families have more commodities including more books, and children are prone to perform better than those in poorer families (Fougère 2007).

Data on Albania show that in families with higher level of parents' education, the poverty of children and young generation decreases (Bici, Dumani 2016). On the other hand, family poverty is not sufficient to explain non-attendance of students, because also a considerable number of children from families in fairer conditions that have completed the nine-year cycle have not enrolled in high schools, as well as, a considerable number of students living in poverty enrolled in high schools (Bici, Dumani 2016).

Table 2. Regression coefficients of influence of explanatory variables for the enrollment in high school

\begin{tabular}{|c|c|c|c|c|c|c|c|c|c|}
\hline \multirow[b]{2}{*}{ Variable } & \multicolumn{3}{|c|}{ Modeli A } & \multicolumn{3}{|c|}{ Modeli B } & \multicolumn{3}{|c|}{ Modeli C } \\
\hline & B & $\begin{array}{l}\text { Odds } \\
\text { Ratio }\end{array}$ & Sig & $\beta$ & $\begin{array}{l}\text { Odds } \\
\text { Ratio }\end{array}$ & Sig & B & $\begin{array}{l}\text { Odds } \\
\text { Ratio }\end{array}$ & Sig \\
\hline \multicolumn{10}{|l|}{ Poverty } \\
\hline Non poor & .633 & 1.882 & 0.000 & 0.363 & 1.438 & 0.000 & 0.527 & 1.694 & 0.000 \\
\hline Poor* & -- & 1 & - & -- & 1 & -- & -- & 1 & - \\
\hline \multicolumn{10}{|l|}{ Region } \\
\hline Center & -0.291 & .748 & 0.000 & -0.200 & 0.794 & o.ooo & -0.328 & 0.720 & 0.000 \\
\hline Coastal & -0.146 & .864 & 0.000 & -0.161 & 0.825 & 0.000 & -0.206 & 0.814 & 0.000 \\
\hline
\end{tabular}




\begin{tabular}{|c|c|c|c|c|c|c|c|c|c|}
\hline \multirow[b]{2}{*}{ Variable } & \multicolumn{3}{|c|}{ Modeli A } & \multicolumn{3}{|c|}{ Modeli B } & \multicolumn{3}{|c|}{ Modeli C } \\
\hline & B & $\begin{array}{l}\text { Odds } \\
\text { Ratio }\end{array}$ & Sig & $\beta$ & $\begin{array}{l}\text { Odds } \\
\text { Ratio }\end{array}$ & Sig & B & $\begin{array}{l}\text { Odds } \\
\text { Ratio }\end{array}$ & Sig \\
\hline Mountain & -0.409 & .664 & 0.000 & -0.136 & 0.841 & 0.000 & -0.307 & 0.736 & 0.000 \\
\hline Tirana* & -- & 1 & - & -- & -- & -- & -- & 1 & -- \\
\hline \multicolumn{10}{|l|}{ Distance } \\
\hline More than 3o' & & & & -1.726 & 0.178 & 0.000 & -1.644 & 0.193 & 0.000 \\
\hline Till 30** & & & & -- & 1 & -- & -- & 1 & -- \\
\hline \multicolumn{10}{|l|}{ Mother education } \\
\hline Without completed education & & & & -0.131 & 0.877 & 0.000 & -0.083 & 0.92 & 0.073 \\
\hline Basic education & & & & -0.138 & 0.871 & 0.000 & -0.009 & 0.991 & 0.493 \\
\hline Secondary or university degree* & & & & -- & 1 & -- & -- & 1 & -- \\
\hline \multicolumn{10}{|l|}{ No of children under 15} \\
\hline One children & & & & & & & 0.304 & 1.355 & 0.000 \\
\hline Two children & & & & & & & 0.47 & 1.6 & 0.000 \\
\hline Three or more children* & & & & & & & -- & 1 & \\
\hline \multicolumn{10}{|c|}{ Presence of parents in the household } \\
\hline None or one parent & & & & & & & -0.208 & 0.812 & 0.000 \\
\hline Both parents* & & & & & & & -- & 1 & \\
\hline
\end{tabular}

Data analysis (LSMS 2012) of the students enrolled after completed nine-year cycle showed that the enrollment in high school is negatively affected when a student lives in a poor family, by lower parent education, by school distance (more than $30 \mathrm{~min}$ ) when there's a large number of children out of labor age in the family, when the student is missing one or both parents (Bici, Dumani 2016).

A non-poor student has 1.9 times chance to enroll in high school than a poor one (Table 2. Model A) when all other variables remaining the same.

A student who walks more than 30 minutes to go to school has 5.6 times higher risk of not enrolling in high school compared to a student whose school is nearer, where the other variables in the model remain the same (Model B). Also, children whose mother's education is up to the basic level have higher risk of not enrolling in high schools compared to children whose mothers completed high school or above (Model B).

By including all explanatory variables in Model C, the risk of non-enrollment in high school of a student who completed nine year cycle is higher in the Central and Mountain Regions than in Tirana; a student in the Central and Mountain region has an almost 1.4 higher risk of not enrolling in high school than a student in Tirana, where the other variables in the equation remain constant.

In families with one and two children up to 15 years old, chances of enrollment in high school are respectively 1.4 and 1.6 times higher than in families with three and more children. A student without one or both parents has a risk of non-enrollment of 1.23 times or $23 \%$ higher than one with both parents. The results show that the explanatory variables included in models $A, B$ have explanatory power $(p<0.01)$ and influence in line with the expected direction of the relation.

\section{4 (Non) systemic development}

The analysis of economic and social developments according to the prefectures in Albania aims to influence development policies in order to reduce regional inequalities. Territorial inequality is present in all countries (Miljanovoć, Miletić, Dordević 2010). according to a new OECD report, income inequality has increased in most developed countries, and regional disparities in housing, safety and air quality inside countries are also increasing. Developed countries such as Australia, Italy, Greece, Canada, ect. are ranked in the first places for the regional inequalities of family income. (oecd.org/regional).

Even though inequality is present everywhere, it differs from one country to the others. It is 
different in Italy and Greece, compared to Albania, a country with living standards far away from those of European countries.

Consumption expenses in the family are dominated by expenses for food and non-alcoholic beverages $(44 \%)$, compared to Europe (12\%); in neighbor countries such as Italy, Greece and Serbia is respectively $14 \%, 17 \%$ and $25 \%$ (oecd.org/regional). This structure in the consumption in Albania is easily vulnerable in the basic needs for living, and even more when the rhythms of economic growth fall, or when the country is going through crisis or natural disasters.

Neo-classical theory suggests that the income of poorer regions will converge, in the long run, to that of the richer regions and that, as a consequence, the growth rate of a region is inversely correlated to its initial level of per capita income (Solow, as cited Aiello, Scoppa 200o). This process of absolute convergence takes place when the regions share the same steady state level, in other words, when exogenous variables - preferences, technology, demographic growth are equal for poor and rich regions (Solow, as cited Aiello, Scoppa 2000). There are several factors that can influence the direction of the relationship between inequality and growth. According to the Kuznets hypothesis (Kuznets, as cited Tafenau, Paas 2011) inequality tends to increase in the course of economic growth in countries at a low development level, while the two phenomena are negatively correlated for developed countries.

The neoclassical growth theories (Solow, as cited Aiello, Scoppa 200o) predict convergence and a decrease of the growth speed in the course of development - a negative relationship between growth and regional disparities (Kuznets, as cited Tafenau, Paas 2011).

In Albania, in addition to high divergences in economic development compared to Europe, there is very low GDP per capita and an extreme differentiation on territorial divisions, municipalities and communes (measured by local own revenues, and in the past by poverty indicators) (Boeckhout, McClements, Girejko, Karaev, Kuqi, Lekaj, Mançellari, Marinov, Murthi, Shutina, Toto (2010).

The sectorial analysis focuses in the special treatment of each developmental indicator and supports the integrated analysis, but particularly they lack the wider context, the synthetic context of developments. Factor analysis can reduce data dimensionality from many variables to a list of factors, one or few factors.

In the factor analysis there were considered seven variables for the demographic, economic and social dimensions.

Demographic dimension: a. Total dependency ratio; b. Fertility

Economic dimension: a. Gross Domestic Production per capita (Ln GDP/capita); b. Proportion of population in the lowest quintile of wealth.

Social dimension: a. Net attendance ratio in high school; b. Proportion of persons 25-64 years old holding a university degree or more, c. Average number of inhabitants per doctor and nurse in the primary medical service.

The factor analysis model results appropriate for the variables included in the model $(K M O=$ $0.753, p<.0001$ ), from all variables one factor was constructed. Values of communality that explain the variance of each variable from the common factor vary from o.6 to o.9. Prefectures of Kukës, Dibër, Elbasan in one side of the axis and Tiranë, Vlorë, Durrës on the other side are very much distanced from the other prefectures (Figure 7).

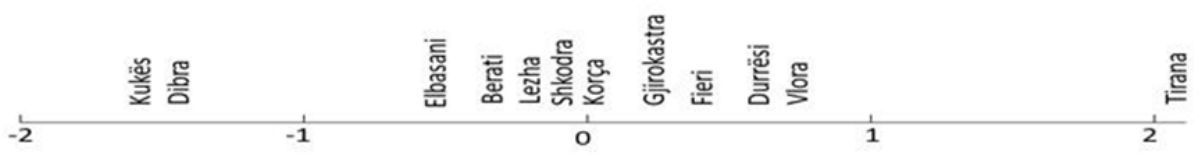

Figure 7. Ranking of prefectures according to the economic and social development factor, 2018 
A similar analysis has been done in 1998 (Dumani 2001) where the economic and social developments in prefectures had the following ranking (Figure 8). Fier prefectures shows the most visible improvement in ranking of all indicators for the period 1998 - 2018, whereas Berat has fallen places in ranking (Figure 7, Figure 8). Above the axis, Tirana has increased its distance from the other prefectures. Meanwhile, prefectures of Kukës, Dibër and Elbasan continue to rank the last almost keeping the same distance from the other prefectures.

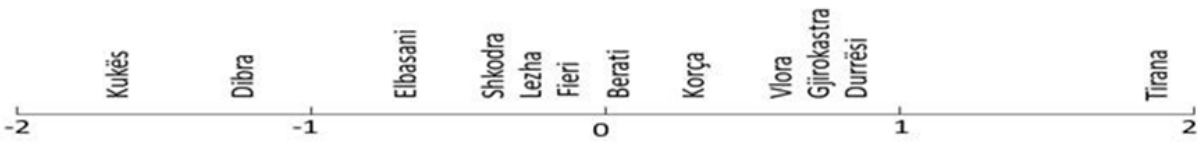

Figure 8. Ranking of prefectures according to the economic and social development factor, 1998

By comparing the estimations of economic and social developments of Albania in 2018 with those in $1998^{8}$, it is observed similar ranking of the prefectures. More than half of the prefectures maintained the same ranking.

With the exception of Tiranë on one side and prefectures of Kukës and Dibër on the other, developments in other prefectures show lower variability in 2018 compared to 1998.

By comparing the prefectures, it is evident that those with relatively lower developments are Kukës, Dibër, Elbasan, and those with relatively higher developments are Tirana, Vlora, Durrës, Fier and Gjirokastër (Figure 9).

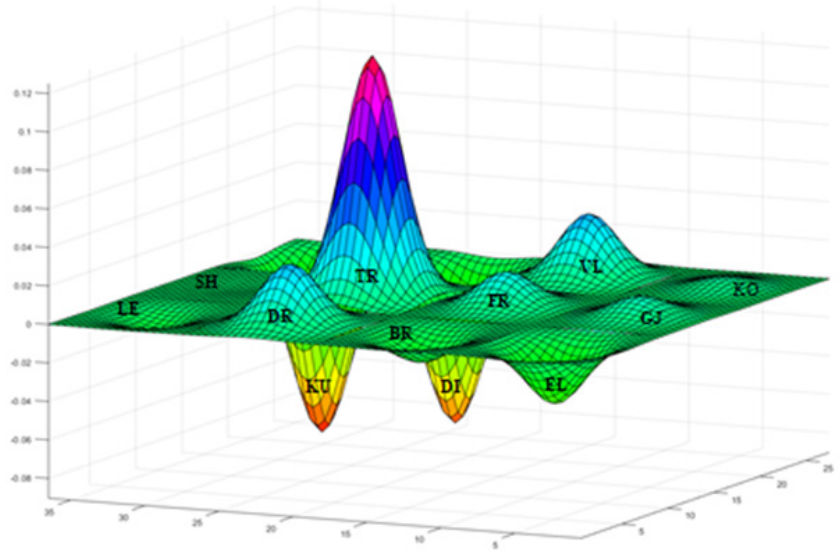

Figure 9. Social and economic development in prefectures according to the principal factor, Albania 2018

The signs of the integrated indicator are arbitrary and aim to evidence the distances in developments of prefectures.

\footnotetext{
${ }^{8}$ The purpose of this comparison is to give a configuration of all developments despite of any limitation on a specific variable for both years.
} 
From a proportion point of view, the evaluation of economic and social developments according to prefectures shows an Albania "with many Albania-s" (Figure 10). Despite of improvements in many indicators in Albania and according to prefectures, the prefectures' positions remain almost the same ( $r \mathrm{~s}=0.888, p<.01$ ) with those of $2-3$ decades ago (Dumani 2001). It is evidence that the rhythms of works have been similar, without managing to bring development status closer, less unequal.

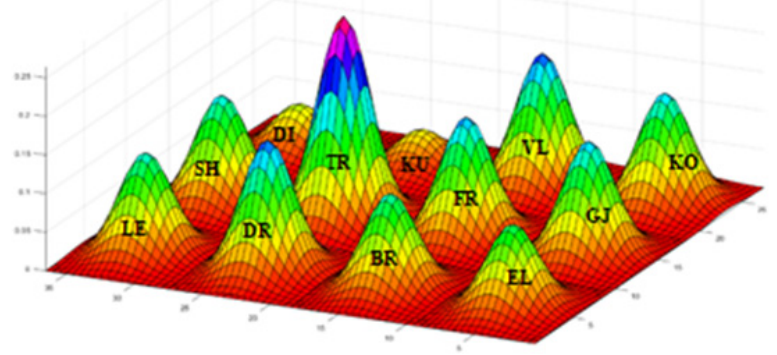

Figure 10. Visual inspection of economic and social developments in Albania's prefectures, 2018

Inequality of social and economic developments among prefectures is evident. But how distant is the inequality within each prefecture? Let's refer to Tirana municipality, where the economic and social activity generally performs better.

A previous study (Dumani, Bici, Dumani, Subashi 2018) showed that developments in the administrative units of Tirana were far away from the municipality's average. In peripheral zones of Tirana, the developments rate is much lower, especially in Units 6 and 11 (Figure 11). In these units, families have more members, more children and elder people in charge of, more unemployment, more poverty, more extreme poverty, more inhabitants per room, less consumption per capita, less schooling, more inequality in education than in other units. Unemployment and poverty are $2-3$ times higher than the units closer to the center of Tirana.

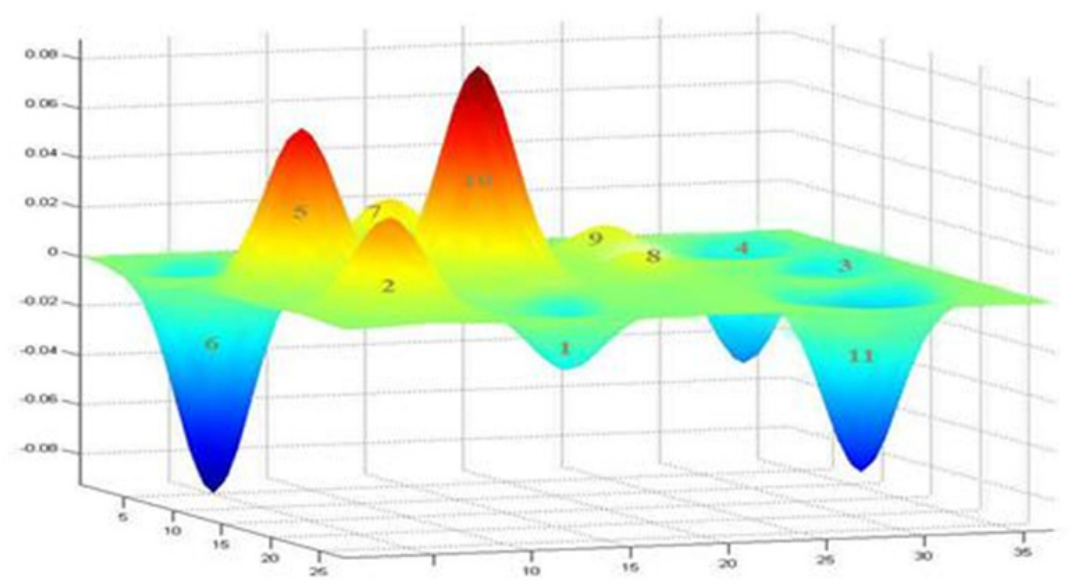

Figure 11. Social and economic development in prefectures according to the principal factor, Tirana 2012 
The units with the highest developments are those closer to the center, Units 10 and Unit 5 . Let us refer also to another fact about the distances in development. In Tirana, one in three inhabitants of 21 years old and older has a university degree or above and this is comparable to the EU countries. Whereas in Units 10 and 5 of Tirana, one in two inhabitants has a university degree or above, whereas in Units 6 and 11 this level is $3-4$ times lower (Dumani, Bici, Dumani, Subashi 2018).

The economic and social developments according to the main factor, in prefectures, show a strong variability of development. Both for Albania and for Tirana it is noted that the territorial neighbors are also neighbors in the entirety of economic and social developments. This can create chances for effective intervention such as lowering invariable costs, potential investments at the same time or in chain for some of the territorial units. From this perspective, more pressure on the creativity and initiative will be put and more decision-making centers with function more actively.

New data sources are essential to find out the dimensions of developments and nondevelopments, to potentially influence policy and decision making processes, in order to offer better solutions in education, health, technology, sustainable development, by focusing on economic and social inequalities of the country, in the territorial units and in people's lives.

\section{Conclusions}

The economic and social developments in Albania differ significantly among its prefectures. The prefectures with relatively lower developments are Kukës, Dibër, Elbasan, and those with relatively higher developments are Tirana followed by Vlorë, Durrës, Fier and Gjirokastër.

Some prefectures show developments that are twice as low compared to the other ones that shows higher results. These differences include main indicators such as: GDP per capita, consumer spending per capita, inequalities in wealth distribution, in education, in internet usage (Demographic and Health Survey 2017-2018), in primary care with doctors and nurses, in education and health expenditures.

The economic and social developments of prefectures according to the integrated indicator in 2018 and 1998 show similar ranking and distances. More than half of prefectures maintain the same ranking as in 1998. The prefectures of Kukës, Dibër and Elbasan continue to show relatively less economic and social developments and almost unchanged distance for more than 20 years.

Despite developments and improvements over time, it is evident that the rhythm of development is low and similar in many prefectures. In this evolution, Tirana has become more distant.

With their budget dominated by food expenses, families in Albania, in 2018, spend only $3 \%$ of their budget for education. Expenditures for education in the family budget is lower in Dibër (1.2\%), in Elbasan (1.3), in Lezhë and Shkodër (1.5\%). The government expenditures for education in 2018 reached 3.5\% of GDP (hdr.undp.org, 2018), a low percentage compared to the majority of European countries.

High school enrollment is in low levels in both country and prefectures. The lowest net attendance ratio for high school is in prefectures of Dibër, Kukës and Elbasan. Even the proportion of persons (25 - 64 years old) with university degree is significantly lower than the level of EU countries; only Tirana is comparable to EU countries. The other prefectures are almost twice as low as Tirana.

The analysis of enrollment of high school both for the prefectures and the whole country emphasizes the importance and influence of other importan factors such as parents' education, poverty, family size, absence of parent in the family, school distance, all of them risk factors (R. Bici et B. Dumani, 2016).

\section{Recommendations}

Albania should know systemic developments with quite a faster rhythm, distribute progress everywhere, decrease distances in development. The higher rhythm of development for everyone 
demands a challenging and reforming actions, ambitious changes in the production and consumption models aiming at becoming less unequal within the country and compared to the European standards.

Even though the inherited levels have their burden, Albania needs a more efficient mobilization of economic, financial and human resources, in order to accelerate progress and to measure development not just by comparing to the past but to the developed European countries.

Special attention in the development policy should be paid to the prefectures with lower economic and social developments, Kukës, Dibër and Elbasan, by giving priority to the developmental factors. Concrete programs and projects with a territorial approach, social targeting of educational policies for children in poor families and orphans demand prioritizing in the developmental policies.

In order to stimulate and expand the high school education attendance, along with the education institutions, also the parents, families and society should be involved more in the ideology of children education. "Changing society by to change school, changing schoole to change society." is quoted in the header of the French magazine "Cahiers pedagogique".

Albania, a country that seeks the developed Europe, a country with development potential, an increasing touristic destination, with a young population, should target the widening and improvement of education in order to fill its environment with more schooling, more qualitative education, innovation and technology.

\section{References}

Aiello, F., \& Scoppa, V. (200o). Uneven regional development in Italy: explaining differences in productivity levels. Giornale degli Economisti e Annali di Economia, pp. 270-298.

Betti, G., Bici, R., Neri, L., Sohnesen, T. P., \& Thomo, L. (2018). Local Poverty and Inequality in Albania. Eastern European Economics, 56(3), pp. 223-245.

Bici,R. and Dumani, B. (2016). Determinants of Low Net Enrollment Rate to Secondary Education, Journal of Science, Innovation and New Technology 17 (1): pp. 7-15.

Boeckhout, S., McClements, C., Girejko. R (editor)., Karaev. A., Kuqi, I., Lekaj. E., Mançellari, A., Marinov, V., Murthi, M., Shutina, D., \& Toto, R. (2010). Regional Disparities in Albania Integrated Support for Decentralization Project "Working for Regional Development", pp. 13-30.

Census of Population and Housing. (2018). Retrieved from http://instat.gov.al/en/themes /censuses/ census-ofpopulation-and-housing/

Claude, Pair. (200o). L'école devant la grande pauvreté, Revue Quart Monde, №174, Passion d'apprendre, Revue Quart Monde document.php?id=2158

Dataset [online]., data.uis.unesco.org/Index.aspx?datasetCode=EDULIT_DS.

Demographic and Health Survey 2017 - 2018. (n.d.). Retrieved from https://microdata.worldbank.org/index.php /catalog/3404, 10- 8 .

Dumani, B., Bici, R., Dumani, N., Subashi, B., \& Kondi, A. (2018). Dissemination of Demographic and SocioEconomic Developments in Tirana with Special Attention to Youth Education. Journal of Educational and Social Research, 8(2), pp. 93-108.

Dumani, B., Bici,R., Dumani, N. (2017). Demand and Supply in Secondary Education in Albania, LAP,Lambert Academic Publishing, pp. 10-31.

Dumani, B. (2001). Profile manaxhimi të paartikuluar në zhvillimet ekonomike e sociale të pas 9o-ës, Ekonomia dhe Biznesi, Fakulteti i Ekonomisë, Nr. 4(8), pp. 15-23.

Education_in https: [online] //en.wikipedia.org > wiki > Education_in.

Fougère, D. (2007). Grande pauvreté et politiques éducatives. L'actualité éducative du $\mathrm{N}^{\circ} 451$ [Online], www.cahiers Pedagogiques.com

Henaff, N., Lange, M. \& Martin, J. (2009). Revisiter les relations entre pauvreté et éducation. Revue Française de Socio-Économie, 3(1), pp. 187-194.

Household Budget Survey (2018). Retrieved from http://www.instat.gov.al/en/themes/socialcondition/household-budget-survey/publications/2019/household-budget-survey-2018/

Human Development Reports. (2018). Retrieved from http://www.hdr.undp.org/en/content/human-developmentindices-indicators-2018-statistical-update 
Iliev, D. (2018). Regional inequalities and contemporary problems in regional tourism development: A case of Macedonia. Anatolia, pp. 1-11.

Indicator/NY.GDP.PCAP.PP.CD https://data.worldbank.org/indicator/NY.GDP.PCAP.PP.CD.

Instat., (2018). Employment and unemployment, www.instat.gov.al, publications 2018.

List of countries by median age. (2020, June 02). Retrieved from https://en.wikipedia.org/wiki/ List_of_ countries_by_median_age.

Mazerolle, F. (2005). Démographie économique, Vuibert, Paris.

Miljanović, D., Miletić, R., \& Đorđević, J. (2010). Regional inequality in Serbia as a development problem. Acta Geographica Slovenica, 5o(2), pp. 253-275.

Psycharis, Y., Rovolis, A., Tselios, V., \& Pantazis, P. (2014), Economic Crisis and Regional Development in Greece. Region et Developpement, pp. 39-85.

Regional inequality. (2016). Oxford Reference; [online] https://www.oecd.org/regional/regional- inequalitiesworsening-in-many-countries.htm, Jun 16, 2016

Tafenau, E \& Paas, T. (2011). "Regional inequality and economic growth: interactions of the relationship with the level of economic development and speed of growth" ERSA conference papers ersa1o p938, European Regional Science Association.

\section{Appendixes: Glossary}

The Human Development Index is a synthetic index of longevity, education and income per capita, which is used for ranking countries in four levels of human development. A country marks a higher HDI when longevity is higher, educational level is higher and the gross national income (GNI) per capita is higher.

Wealth Index is a measurement related to the inequalities in the family income, use of medical services, results of health status (Rutstein et al, 200o. The wealth index is built by allocating a weight to each asset (wealth) in a family through main component analysis. The results are multiplied according to families and individuals are ranked as per family where they belong. The sample is then divided in population quintiles, five groups with the same number of individuals each. On national scale, around $20 \%$ of population pertains to each wealth quintile.

Gini Coefficient is a coefficient for measurement of inequality in the distribution of wealth. Its value varies from o if wealth is distributed equally to 1 if wealth distribution is totally unequal or concentrated.

Labor Force includes employed and unemployed persons.

Not Economically Active Population includes all persons that are not classified as employed or unemployed (ie. pupils/students, housewives, retired, incapable, discouraged unemployed).

Employment Ratio is the ratio of employed 15-64 years old against the population in working age.

Unemployment Ratio is the ratio of unemployed against the labor force.

Participation in Labor Force ratio is the ratio of labor force against the population in working age.

Educational Attainment/Achievement expresses the human capital formation process through completion of different levels of education.

School Attendance indicates the actual registration of different ages in school activities.

Net Attendance Ratio (NAR) is determined as the ratio of number of persons in the official group age to enroll in an educational institution against the general number of persons in the official age. Differently from the educational achievement which indicates those who have completed a certain level, the indicators of participation are a snap shot (NAR shows participation in the nine year cycle for the population of 6-14 years and in high school for population of 15-17 years old. A NAR of $100 \%$ shows that all children in a school cycle are participating in accordance to the official age.

Prefectures: Berat (BR), Dibër (DI), Durrës (DR), Elbasan (EL), Gjirokastër (GJ), Korçë (KO), Kukës (KU), Lezhë (LE), Shkodër (SH), Tiranë (TR), VLorë (VL).

Regions: According to LSMS 2012, the coastal region includes Lezha, Kurbini, Kavaja, Mallakastra, Lushnja, Delvina, Saranda, Durrësi, Fieri, Vlora. The central region includes Kuçova, Skrapari, Kruja, Peqini, Gjirokastra, Përmeti, Tepelena, Devolli, Kolonja, Pogradeci, Mirdita, Puka, Malësia e Madhe, Shkodra, Elbasani, Berati, Korça, Mati and the agricultural area of Tirana. The mountainous region includes Tropoja, Hasi, Kukësi, Dibra, Bulqiza, Librazhdi, Gramshi.

Family Economic Entity (FEE) indicates a setup where a group of persons, blood related or not, inhabit together and share one common economy partially or totally. 